\title{
A PHARMACOEPIDEMIOLOGIC STUDY OF DRUG INTERACTIONS IN A BRAZILIAN TEACHING HOSPITAL
}

\author{
Joice Mara Cruciol-Souza, João Carlos Thomson
}

Cruciol-Souza JM, Thomson JC. A pharmacoepidemiologic study of drug interactions in a brazilian teaching hospital. Clinics. 2006;61(6):515-20.

PURPOSE: Although drug-drug interactions constitute only a small proportion of adverse drug reactions, they are often predictable and therefore avoidable or manageable. There are few studies on drug-drug interactions from Brazil. This study aimed to assess the frequency of drug-drug interactions in prescriptions and their potential clinical significance in patients of a Brazilian teaching hospital.

METHODS: From January to April 2004, a sample of 1785 drug prescriptions was drawn from a total of 11,250. Drug-drug interactions were identified by using Micromedex ${ }^{\circledR}$ DrugReax ${ }^{\circledR}$ System. Patients' records with major drug-drug interactions were reviewed by a pharmacist and a medical doctor looking for signs, symptoms, and lab tests that could indicate adverse drug reactions due to such interactions.

RESULTS: From the 1785 prescriptions examined, 1089 (61\%) were from the male adult ward. Patients' average age was 52.7 years $(\mathrm{SD}=18.9$; range, 12-98). The median number of drugs in each prescription was 7 (range, 2-26). At least 1 drug-drug interactions was present in $887(49.7 \%)$ prescriptions. Regarding the severity of the clinical result, the interactions were classified as minor $(20 ; 2.3 \%)$, moderate $(184 ; 20.7 \%)$, major $(30 ; 3.4 \%)$, and undetermined because of an incidence of more than 1 interaction in a single patient $(653 ; 73.6 \%)$. From the 30 patients with major interactions, $17(56.7 \%)$ presented adverse drug reactions induced by exposure to a major drug-drug interaction.

CONCLUSIONS: Patients did suffer adverse drug reactions from major drug-drug interactions. Many physicians may be unaware of drug-drug interactions. Education, computerized prescribing systems and drug information, collaborative drug selection, and pharmaceutical care are strongly encouraged for physicians and pharmacists.

KEYWORDS: Prescriptions. Drug-drug interactions. Teaching Hospital. Pharmacovigilance. Drug utilization.

\section{INTRODUCTION}

Drug-drug interactions (DDI) are a cause of adverse drug reactions, resulting in adverse outcomes associated with drug therapy. ${ }^{1,2}$ The literature on drug interactions is generally related to DDI mechanisms, drug pharmacokinetic studies, and clinical cases. ${ }^{3,4}$ The pharmacoepidemiology of drug interactions has been less explored.

Hospital Universitário da Universidade Estadual de Londrina - Londrina/ PR, Brasil.

Email: jcruciol@yahoo.com.br

Received for publication on May 09, 2006.

Accepted for publication on August 18, 2006.
Hospital stay may be associated with relevant changes in patient care. In general, close monitoring of medical care is guaranteed during the hospital stay. Patients without therapeutic care are more exposed to drug-related problems that may include potential DDI. ${ }^{5,6}$

At least $15 \%$ of the patients admitted to hospitals have 1 DDI at admission. ${ }^{1,7-9}$ The risk of DDI can increase in the hospital because new drugs are often added to an existing drug therapy..$^{10}$ Drug-drug interactions are often predictable and, therefore, avoidable or manageable, but the reactions caused by them are mostly unknown. The present study aimed to assess the prevalence of DDI in the hospital prescriptions for adult inpatients and describe their characteristics and the adverse reactions caused by 'major' DDI. 


\section{METHODS}

A drug utilization study was carried out using data from the prescriptions of a Brazilian teaching hospital. The hospital is a 300-bed teaching public institution that is also a referral center for hospital care. During the period of this study, hospitalization length for inpatients varied from 1 to 8 days. The hospital, as for many in Brazil, does not have electronic prescription capability. Once a day, medical doctors prescribe drugs necessary for 24 hours of hospitalization. More than 1 drug can be prescribed at the same time.

During a 4-month period, approximately 11,250 prescriptions were dispensed. Only patients who were 12 years old or more were in these wards, separated by gender. Prescriptions containing 2 or more drugs were selected once a week from January to April 2004. Prescriptions for patients of both genders were included in this study. All drug groups were included and classified according to the Anatomical-Therapeutic-Chemical Classification (ATC code, level 2 - WHO, 2004). ${ }^{11}$ The total number of prescriptions selected for this study was 1785 , which corresponds to $15.8 \%$ from the entire population. The ratio of men to women in the study was maintained as $60 / 40$, to match the hospital's male/female ward ratio.

Drug-drug interactions were identified using the Micromedex ${ }^{\circledast}$ DrugReax $^{\circledR}$ System. ${ }^{12}$ The DrugReax System information contains a dictionary of more than 8,000 unique drug terms, and it distinguishes trade names from equivalent generic names, eliminating possible duplication of interaction data on the screen. This system is drug-specific rather than class-specific. All the drugs prescribed must be selected on the screen to have DDI calculated. Up to 128 concurrent clinical conflicts can be reviewed. The program also provides information about clinical consequences or adverse drug reactions that could result from a DDI; it characterizes the underlying mechanism and classifies onset of adverse drug reactions (rapid, delayed), severity (minor, moderate, major), and how well the DDI is documented in the literature (excellent, good, fair, poor, unlikely). The Micromedex DrugReax System's definitions about onset, severity, and documentation were accepted for use in the study, as follows: ${ }^{12}$

\section{Onset}

- Rapid: Onset of clinical conflict or adverse effects expected within 24 hours of drug administration.

- Delayed: Onset of clinical conflict or adverse effects not expected to appear within the first 24 hours following drug administration.

\section{Severity}

- Major: The interaction may be life-threatening and/or require medical intervention to minimize or prevent serious adverse effects.

- Moderate: The interaction may result in an exacerbation of the patient's condition and/or require an alteration in therapy.

- Minor: The interaction would have limited clinical effects. Manifestations may include an increase in the frequency or severity of side effects but generally would not require a major alteration in therapy.

\section{Documentation}

- Excellent: Controlled studies have clearly established the existence of the interaction.

- Good: Documentation strongly suggests the interaction exists, but well-controlled studies are lacking.

- Fair: Available documentation is poor, but pharmacologic considerations lead clinicians to suspect the interaction exists; or, documentation is good for a pharmacologically similar drug.

- Poor: Documentation is poor, such as limited case reports; but the clinical conflict is theoretically possible.

- Unlikely: Documentation is poor and lacks a sound pharmacologic basis.

Each prescription with a 'major' DDI led to a patient record, which was examined by a physician and a pharmacist to find signs, symptoms, and lab test results that could confirm adverse reactions resulting from the 'major' DDI.

Data were presented as proportions, means and standard deviations, or medians. Descriptive analysis was conducted in Excel $^{\circledR}$ version 7.0.

This study was previously evaluated and approved by the Committee of Ethic of the University.

\section{RESULTS}

\section{Prescriptions}

In this study, 1785 prescriptions were analyzed; 1089 $(61 \%)$ were from the male adult ward and 696 (39.0\%) from female ward. The average age of the patients was 52.7 \pm 18.9 years (range, 12-98 years). Prescriptions came from patients who had been hospitalized in the following areas: gastroenterology $(279 ; 15.6 \%)$, orthopedics $(269 ; 15.1 \%)$, cardiovascular $(240 ; 13.4 \%)$, emergency surgery (146; $8.2 \%)$, neurology $(143 ; 8.0 \%)$, pneumology $(103 ; 5.8 \%)$; and others $(605 ; 33.9 \%)$. 


\section{Number of drugs prescribed}

Each prescription had a median of 7 drugs (range, 226 different drugs). Analgesics, drugs for gastrointestinal disorders, and antibacterial drugs for systemic use were the most prescribed therapeutic drug classes. Metamizole sodium $(\mathrm{n}=1138 ; 63.8 \%)$ was the analgesic present in almost all prescriptions, followed at a distance by tramadol $(\mathrm{n}=289 ; 16.2 \%)$. Metoclopramide $(\mathrm{n}=1116 ; 62.5 \%)$ was the most prescribed drug for functional gastrointestinal disorders. Metronidazole $(\mathrm{n}=188,10.5 \%)$ and ciprofloxacin $(\mathrm{n}=151,8.5 \%)$ were the most prescribed antibacterial drugs for systemic use. The median number of therapeutic drug classes in each prescription was 4 (range, 1-8).

\section{Prevalence of drug-drug interactions (DDI)}

From the 1785 prescriptions analyzed, DDI was identified in 887 (49.7\%). Prescriptions presenting DDI came from cardiovascular $(\mathrm{n}=192 ; 21.6 \%)$, gastroenterology $(101 ; 11.4 \%)$, emergency surgeries $(94 ; 10.6 \%)$, orthopedics $(90 ; 10.1 \%)$, neurology $(73 ; 8.2 \%)$, pneumology $(50$; $5.6 \%)$, and others $(287 ; 32.4 \%)$. The number of DDI per prescription varied from 1 to 22 with a median of 3 . Captopril + spironolactone $(18 ; 2.0 \%)$ and digoxin + hydrochlorothiazide $(16 ; 1.6 \%)$ were the most common 'major' DDI in our sample.

Only 234 (26.4\% of 887 ) prescriptions had a single DDI, while 653 (73.6\% of 887 ) prescriptions presented more than 1 . Regarding the 234 prescriptions having only 1 DDI, an underlying pharmacodynamic mechanism was identified for $102(43.5 \%)$, while a pharmacokinetic mechanism was identified for 44 (18.8\%); other types of mechanisms were identified for 83 (35.5\%), and mechanisms were unknown for $5(2.2 \%)$. The onset of expected adverse drug reaction as a result of a DDI was classified as 'delayed' in 114 prescriptions $(48.7 \%)$, while it was 'rapid' in 120 $(51.3 \%)$. The documentation in the literature for DDI was classified as 'excellent' or 'good' for 69 (29.5\%) prescriptions, 'fair' for 120 (51.3\%), 'poor' for 41 (17.5\%), and 'unlikely' for 4 (1.7\%) From the 234 prescriptions with a single DDI, the following classifications of the severity of the potential adverse drug reaction were made: 'major', 30 prescriptions (12.8\%); 'moderate', 184 (78.6\%); and 'minor', $20(8.6 \%)$.

\section{Clinical relevance}

The DDI detected in our sample were easily manageable, either by substituting another drug $(256 ; 28.9 \%)$, by adjusting the dose $(166 ; 18.9 \%)$, by supplementing the pre- scribed drugs with another drug $(71 ; 8.0 \%)$, or by closely monitoring clinical symptoms and lab tests results (52; $5.9 \%)$. However, at least 64 prescriptions (7.2\%) had 1 'major' DDI that should have been avoided. No management was suggested by Micromedex for 278 prescriptions $(31.3 \%)$.

The expected adverse drug reactions resulting from the DDI were hypertension $(45 ; 19.2 \%)$, hemorrhage $(34$; $14.5 \%)$, inflammation $(12 ; 5.1 \%)$, hypoglycemia $(8 ; 3.4 \%)$, and others $(135 ; 57.7 \%)$.

The 30 prescriptions with 1 'major' DDI led to patient records, which were examined to look for evidence that suggested that adverse drug reactions resulted from the DDI. The following DDI and adverse drug reactions were identified in $17(56.7 \%)$ of these 30 examined records: acetylsalicylic acid + warfarin [gastric hemorrhage], amiodarone + digoxin [digitalic toxicity], amitriptyline + clonidine [hypertension], captopril + spironolactone [hyperkalemia and changes in the ECG], potassium chloride + spironolactone [hyperkalemia], digoxin + hydrochlorothiazide [digitalic toxicity], and isoniazid + rifampin [hepatotoxicity]. See Table 1 for more information about the patients whose prescriptions had a 'major' DDI and whose records showed signs and symptoms of adverse drug reactions.

\section{DISCUSSION}

The present study highlights the detection of DDI prevalence using a computer program to check prescriptions for inpatients in a Brazilian teaching hospital. In our study, almost $50 \%$ of the prescriptions presented at least 1 DDI. This prevalence was higher than others found in similar Brazilian studies..$^{9,13,14}$ Miyasaka and Atallah ${ }^{9}$ found that in prescriptions for psychiatric patients, $22 \%$ had DDI; Meiners and Bergsten-Mendes ${ }^{13}$ found that in pediatric prescriptions, $32 \%$ had DDI. This discrepancy could have occurred because of the different designs of the studies. Dias ${ }^{14}$ found that in prescriptions of a Brazilian hospital in a study having a design similar to ours, $38 \%$ had DDI. Possible causes of this difference in DDI prevalence may be due to aspects related to population, year and period of study, the sequence of actions and decisions used to provide drug therapy, hospital pharmacists' work, and electronic drug information availability in the hospital.

Several DDI were detected in most of the prescriptions of our sample. We did not find information about the clinical consequences of more than 1 DDI in the literature; however, if 1 DDI can be life-threatening, we believe it is safe to assume that 2 or more DDI may even more hazardous for the patient. 
Table 1 - Number of patients whose prescriptions had a 'major' drug-drug interaction (DDI) and whose records showed signs and symptoms of adverse drug reactions (ADR), by disease classification and age

\begin{tabular}{|c|c|c|c|c|c|c|c|c|}
\hline \multirow{2}{*}{$\begin{array}{l}\text { Disease classification } \\
\text { at admission }\end{array}$} & \multirow{2}{*}{$\begin{array}{l}\text { Age range } \\
\text { (years) }\end{array}$} & \multicolumn{7}{|c|}{ Number of patients with ADRas a result of a 'major' DDI pair } \\
\hline & & $\mathrm{ASA}+\mathrm{W}^{\mathrm{a}}$ & $\mathrm{A}+\mathrm{D}^{\mathrm{b}}$ & $\mathrm{A}+\mathrm{C}^{\mathrm{c}}$ & $\mathrm{C}+\mathrm{S}^{\mathrm{d}}$ & $\mathrm{P}+\mathrm{S}^{\mathrm{e}}$ & $\mathrm{D}+\mathrm{H}^{\mathrm{f}}$ & $\mathrm{I}+\mathrm{R}^{\mathrm{g}}$ \\
\hline \multirow[t]{3}{*}{ Cardiovascular } & $<59$ & 2 & 1 & 2 & 1 & - & - & - \\
\hline & $60-79$ & - & - & - & - & 1 & - & - \\
\hline & $>80$ & 1 & - & - & - & - & - & - \\
\hline \multirow[t]{3}{*}{ Gastroenterologic } & $<59$ & - & - & - & - & - & - & 1 \\
\hline & $60-79$ & - & - & 1 & 1 & 1 & - & - \\
\hline & $>80$ & - & - & - & - & - & - & - \\
\hline \multirow[t]{3}{*}{ Neurologic } & $<59$ & - & - & - & - & - & - & - \\
\hline & $60-79$ & 1 & - & - & - & - & - & - \\
\hline & $>80$ & - & - & - & - & - & - & - \\
\hline \multirow[t]{3}{*}{ Pulmonary } & $<59$ & - & - & 1 & - & - & - & - \\
\hline & $60-79$ & - & - & - & 1 & 1 & 1 & - \\
\hline & $>80$ & - & - & - & - & - & - & - \\
\hline $\begin{array}{l}\text { Total patients with } \\
\text { ADR }^{\mathrm{h}}\end{array}$ & 4 & 1 & 4 & 3 & 3 & 1 & 1 & \\
\hline
\end{tabular}

a acetylsalicilic acid + warfarin; ${ }^{\mathrm{b}}$ amiodarone $+\operatorname{digoxin} ;{ }^{\mathrm{c}}$ amitryptiline + clonidine; ${ }^{\mathrm{d}}$ captopril + spironolactone; ${ }^{\mathrm{e}}$ potassium chloride + spironolactone; ${ }^{\mathrm{f}}$ digoxin + hydrochlorothiazide; ${ }^{\mathrm{g}}$ isoniazide + rifampin; ${ }^{\mathrm{h}}$ adverse drug reaction

In our study, only 234 prescriptions (26.4\% from 887 ) presented a single DDI, and 30 of them $(12.8 \%$ of the 234$)$ were expected to have 'major' clinical consequence. More than half of the patients $(56.7 \%$ of the 30$)$ with a 'major' DDI at prescription did present the expected adverse drug reaction during hospitalization time.

We cannot quantify how many of the identified DDI were known by the physicians, but we assume that they were possibly unaware of the potential risk associated with certain combinations. To better quantify the clinical relevance of potential interacting drug combinations during hospital stay, a prospective design would be necessary, including a follow-up long enough after discharge to assess the outcomes of DDI even for those with a delayed onset. Moreover, the clinical relevance of a DDI is often categorized along 2 dimensions, ${ }^{15}$ ie, the expected 'severity' of a patient's physical reaction to a DDI and the 'documentation' (the amount and quality of research that suggest whether a particular DDI will indeed occur in human beings). In fact, the clinical effects of any DDI, regardless of how well it is documented, do not occur in every patient or at the same level of intensity. They depend on patientrelated factors that usually require individual assessment. ${ }^{16}$ However, our results showed that some patients had suffered adverse reactions from 'major' DDI.

The potential adverse clinical consequences resulting from a specific interacting drug combination may sometimes be counteracted by prescribing an additional drug. Moreover, the sequence of drug administration and patientrelated factors may be crucial for the occurrence of adverse effects, but generally, drug interaction programs do not consider these aspects. All these factors could have resulted in the overestimation of the risk of DDI, so evaluations for actual adverse drug effects were done by screening the records of patients who had a 'major' DDI pair prescribed.

To assess the clinical relevance of a DDI, it would be highly recommended to determine how often it appears in prescriptions. Our work followed a pharmacoepidemiologic design, which is one of the contributions of this study. Literature on DDI prevalence is scarce, since drug interaction studies give no information on the total number of patients exposed to each drug combination. ${ }^{3,4}$ Additionally, DDI studies of clinical relevance are often carried out by a small group of volunteers, or arise from case series with specific patients or drugs.

This study focused on the epidemiology of severe DDI caused by drugs prescribed and their clinical manifestations in patients. Limitations of this study were due to the retrospective design.

Other limitations of this study were closely related to the information provided by different sources. There is only a partial agreement among DDI compendia. ${ }^{7,17}$ In this study, a compendium that lists most of the known interactions was used. This may have resulted in an overestimation of DDI in the whole sample.

The 'major' drug interacting combinations have been associated with clinically relevant adverse reactions. ${ }^{12}$

Pharmaceutical care, electronic drug information, and pharmacotherapy evaluation of prescriptions could contribute to better patient health outcomes. ${ }^{18}$

A computerized drug-interaction program may be a valuable and helpful tool to check for DDI, but it has to be combined with clinical pharmacological experience and expertise as well as the knowledge of relevant patient-re- 
lated factors. ${ }^{19,20}$ This also implies that computer programs should place more emphasis on how to detect and deal with the clinical consequences of a DDI.

\section{CONCLUSION}

Drug-drug interaction should be suspected anytime a new or an unexpected effect occurs and complicates the clinical management of a patient in a setting where the patient is receiving at least 2 interacting drugs. ${ }^{21-24}$ This study is a contribution to the epidemiologic data on prevalence of DDI in prescriptions and clinical manifestation of the 'major' DDI.

Brazilian pharmacists are generally involved administratively rather than clinically, ${ }^{25}$ and Brazilian hospitals rarely offer pharmaceutical care or drug information services. ${ }^{26}$ Prescriptions should be screened at least for 'major' DDI. Prescriptions of drugs that are commonly involved in 'major' DDI, like digoxin and warfarin, should be analyzed by a clinical pharmacist prior to drug dispensing. Patients should also be closely monitored for adverse drug reactions.
Education of health professionals, computerized systems for prescription and drug information, as well as collaborative drug selection and pharmaceutical care are some of the possible solutions to the problem. The quality of Brazilian health care practices and drug use process need further investigation. All people deserve to be better cared for.

\section{ACKNOWLEDGEMENTS:}

We thank the State University of Londrina, Brazil for the logistics throughout the research. The study was supported by the Medical and Health Sciences Program of the State University of Londrina. We would like to thank Miss Marli Carletto (Pharm), Miss Fabiana Dalla-Vecchia (Pharm), Mr. Douglas G. Catisti (Pharm) and Mr. Gustavo H. Antonietti (Pharm) for the typing the available prescription data. We also thank Dr. Olavo Franco Ferreira Filho for his contributions to this text. We also thank Mr. Nilton Barbosa (Pharm), Head of Pharmacy, Dr. Sinésio Moreira Jr., Clinical Manager and Dr. Franscisco Eugênio Alves de Souza, Director of the Teaching Hospital of the State University of Londrina.

\section{RESUMO}

Cruciol-Souza JM, Thomson JC. Um estudo farmacoepidemiológico de interações medicamentosas em um hospital universitário brasileiro. Clinics. 2006;61(6):515-20.

INTRODUÇÃO: Embora as interações medicamentosas constituam uma pequena parcela das reações adversas a medicamentos, elas geralmente são previsíveis e às vezes podem ser evitadas. As prevalências de interações medicamentosas em hospitais são escassas no Brasil.

OBJETIVO: Avaliar a prevalência de interações medicamentosas em prescrições hospitalares e seu significado clínico em pacientes de um hospital universitário brasileiro.

MÉTODOS: Uma amostra de 1785 prescrições de enfermaria de adultos foi coletada de um total de 11.250 aviadas no período de janeiro a abril de 2004. As interações medicamentosas foram identificadas pelo Micromedex. Prontuários de pacientes com interações medicamentosas graves foram examinados por um médico e uma farmacêutica a busca de resultados laboratoriais que confirmassem a ocorrência da interação medicamentosa.

RESULTADOS: As prescrições eram de pacientes masculinos $(1089 ; 61 \%)$ em sua maioria. A idade média dos pacientes foi de 52,7 anos ( $\mathrm{DP}=18,9$; variação de 12 a 98 anos). Cada paciente recebeu em média 7 medicamentos (variando de 2 a 26). Ao menos 887 (49,7\%) das prescrições continham interação medicamentosa. As prescrições continham interação medicamentosa classificadas como leve $(55 ; 3.1 \%)$, moderada $(421 ; 23.6 \%)$ e grave $(90 ; 5.0 \%)$. Em $321(17.9 \%)$ prescrições foram encontradas mais de uma interação medicamentosa, cujo resultado clínico é desconhecido. Uma amostra de 33 prontuários com interações medicamentosas graves foram avaliadas, destes, 17 (51.5\%) apresentaram reações adversas a medicamentos induzida por uma interação medicamentosa grave.

CONCLUSÃO: Um grande número de pacientes sofre reações adversas a medicamentos como resultado de interações medicamentosas graves. Acreditamos que a maioria dos médicos desconheça a ocorrência de interações medicamentosas. Educação continuada, sistema computadorizado para prescrição, seleção de medicamentos em parceria com farmacêuticos e monitoramento farmacoterapêutico dos pacientes são recomendações para os profissionais da saúde.

UNITERMOS: Prescrições. Interações medicamentosas. Hospital Universitário. Farmacovigilância. Utilização de Medicamentos. 
1. Gosney M and Tallis R. Prescription of contraindicated and interacting drugs in elderly patients admitted to hospital. Lancet. 1984;2:564-7.

2. Wiffen P, Gill M, Edwards J, Moore A. Adverse drug reactions in hospital patients. A systematic review of the prospective and retrospective studies. Bandolier Extra. 2002;June. Accessed on 19/05/05 at: http:// www.jr2.ox.ac.uk/bandolier/Extraforbando/ADRPM.pdf.

3. Koh T. Risk of torsades de pointes from oral erythromycin with concomitant carbimazole (methimazole) administration. Pacing Clin Electrophysiol. 2001;24:1575-6.

4. McCabe BJ. Prevention of food-drug interactions with special emphasis on older adults. Curr Opin Clin Nutr Metab Care. 2004;7:21-6.

5. Smith L, McGowan L, Moss-Barclay C, Wheater J, Knass D, Chrystyn $\mathrm{H}$. An investigation of hospital generated pharmaceutical care when patients are discharged home from hospital. Br J Clin Pharmacol. 1997;44:163-5.

6. Wiesner C, Hersberger KE, Surber C, Haefeli WE. Drug safety after hospital discharge. Pharm World Sci. 1999; 22:A18.

7. Langdorf M, Fox J, Marwah R, Montague BJ, Hart MM. Physician versus computer knowledge of potential drug interactions in the emergency department. Acad Emerg Med. 2000;7:1321-9.

8. Gaddi G, Holt T, Woods M. Drug interactions in at-risk emergency department patients. Acad Emerg Med. 2002;9:1162-7.

9. Miyasaka L and Atallah A. Risk of drug interaction: combination of antidepressants and other drugs. Rev Saude Publica. 2003;37:212-5.

10. Heininger-Rothbucher D, Bischinger S, Ulmer H, Pechlaner C, Speer G, Wiedermann CJ. Incidence and risk of potential adverse drug interactions in the emergency room. Resuscitation. 2001;49:283-8.

11. WHO - World Health Organization. Anatomic Therapeutic and Chemical Classification of Drugs. Accessed in 07/21/2004 at: http:// www.whocc.no/atcdd.

12. Klasco RK (editor): DRUG-REAX ${ }^{\circledR}$ System. Thomson MICROMEDEX, Greenwood Village, Colorado (Edition expires [2005]).

13. Meiners M, Bergsten-Mendes G. Prescrição de medicamentos para crianças hospitalizadas: como avaliar a qualidade? Rev Assoc Med Bras. 2001;47:332-7.
14. Dias MF. Interações Medicamentosas potenciais em ambiente hospitalar [Mestrado]. Campinas, SP: Universidade Estadual de Campinas; 2001.

15. Limbird LE, Hardman JG, Goodman LS, Gilman AG. Goodman and Gilman's The Pharmacological Basis of Therapeutics, 10th ed. Macmillan Publishing Co, New York, NY, 2001.

16. Roberts JS, Watrous ML, Schulz RM, Mauch RP, Nightengale BS Quantifying the clinical significance of drug-drug interactions: scaling pharmacists' perceptions of a common interaction classification scheme. Ann Pharmacother. 1996;30:926-34.

17. Jankel CA and Fitterman LK. Epidemiology of drug-drug interactions as a cause of hospital admissions. Drug Saf. 1993;9:51-9.

18. Malone DC, Abarca J, Hansten PD, Grizzle AJ, Armstrong EP, Van Bergen RC, et al. Identification of serious drug-drug interactions: results of the partnership to prevent drug-drug interactions. J Am Pharm Assoc (Wash DC). 2004;44:142-51.

19. Leape LL, Bates DW, Cullen DJ, Cooper J, Demonaco HJ, Gallivan T, et al. Systems analysis of adverse drug events. JAMA. 1995;274:35-43.

20. Bond CA, Raehl CL, Franke T. Medication errors in United States hospitals. Pharmacotherapy. 2001;9:1023-36.

21. Gray MD and Felkey BG. Computerized prescriber order-entry systems: evaluation, selection and implementation. Am. J. Health-Syst Pharm. 2004;61:190-7.

22. Wiltink EH. Medication control in hospitals: a practical approach to the problem of drug-drug interactions. Pharm World Sci. 1998;20:173-7.

23. Raschetti R, Morgutti M, Menniti-Ippolito F, Belisari A, Rossignoli A Longhini $\mathrm{P}$, et al. Suspected adverse drug events requiring emergency department visits or hospital admissions. Eur J Clin Pharmacol. 1999;54:959-63.

24. Köhler GI, Bode-Boger SM, Busse R, Hoopmann M, Welte T, Boger RH. Drug-drug interactions in medical patients: effects of in-hospital treatment and relation to multiple drug use. Int J Clin Pharmacol Ther. 2000;38:504-13.

25. Netto SJR, Yamamoto JA, Bissoqui LY, Quiqueto MB, Sato H, CruciolSouza JM. Características da Prática Farmacêutica em Farmácias de Londrina-Pr. Pharmacia Brasileira. 2003;35:53-54.

26. Osório-de-Castro CGS, Castilho SR. Diagnóstico da Farmácia Hospitalar no Brasil. 1 ed. Rio de Janeiro, RJ: ENSP; 2004. 